\title{
Cellular differentiation determines the expression of the hypoxia-inducible protein NDRGI in pancreatic cancer
}

\author{
E Angst', S Sibold', C Tiffon', R Weimann², B Gloor', D Candinas' and D Stroka*, \\ 'Department of Clinical Research, Visceral and Transplant Surgery, University Hospital Bern, Murtenstrasse 35, Bern 30 I0, Switzerland; ${ }^{2}$ Institute of \\ Pathology, University of Bern, Bern 3010, Switzerland
}

\begin{abstract}
N-myc downstream-regulated gene-I (NDRGI) is a recently described hypoxia-inducible protein that is upregulated in various human cancers. Pancreatic ductal adenocarcinoma, called pancreatic cancer, is a highly aggressive cancer that is characterised by its avascular structure, which results in a severe hypoxic environment. In this study, we investigated whether NDRGI is upregulated in these tumours, thus providing a novel marker for malignant cells in the pancreas. By immunohistochemistry, we observed that NDRG I was highly expressed in well-differentiated cells of pancreatic cancer, whereas the poorly differentiated tumour cells were negative. In addition, hyperplastic islets and ducts of nonquiescent pancreatic tissue were positive. To further explore its selective expression in tumours, two well-established pancreatic cancer cell lines of unequal differentiation status were exposed to $2 \%$ oxygen. NDRGI mRNA and protein were upregulated by hypoxia in the moderately differentiated Capan-I cells; however, its levels remained unchanged in the poorly differentiated Panc-I cell line. Taken together, our data suggest that NDRGI will not serve as a reliable marker of tumour cells in the pancreas, but may serve as a marker of differentiation. Furthermore, we present the novel finding that cellular differentiation may be an important factor that determines the hypoxia-induced regulation of NDRG I. British Journal of Cancer (2006) 95, 307-313. doi:I0.1038/sj.bjc.6603256 www.bjcancer.com
\end{abstract}

Published online II July 2006

(C) 2006 Cancer Research UK

Keywords: pancreatic cancer; NDRGI; cellular differentiation; hypoxia

Pancreatic ductal adenocarcinoma, further mentioned as pancreatic cancer, is one of the most aggressive cancer with an overall 5 -year survival of merely $4 \%$ in Western countries (http:// seer.cancer.gov/csr/1975_2000/). It is described as a poorly differentiated tumour type that aggressively invades surrounding tissue and metastasises early to distant organs. Pancreatic cancer is usually undiagnosed until it has reached an advanced symptomatic stage, and consequently, only $15-20 \%$ of all patients are candidates for a surgical resection (Warren et al, 1983). Among those patients amenable to surgical resection, tumour characteristics including size and degree of differentiation are important independent prognostic factors (Sohn and Yeo, 2000).

A major characteristic of pancreatic cancers is an avascular morphology, which results in a poor blood and oxygen supply. Consequently, pancreatic tumours are generally hypoxic, which has been proven by intratumoral $p \mathrm{O}_{2}$ measurements (Koong et al, 2000). Hypoxia can contribute significantly to an aggressive behaviour of pancreatic cancers through the hypoxia-induced expression of proangiogenic factors, such as vascular endothelial growth factor (VEGF) and interleukin-8 (Shi et al, 1999; Buchler et al, 2003; Hotz et al, 2005). Tumour hypoxia also has been shown to increase tumour growth and the metastatic potential of pancreatic cancer cells (Niizeki et al, 2002; Buchler et al, 2004). Additionally, pancreatic cancers highly express the hypoxia-

*Correspondence: Dr D Stroka; E-mail: deborah.stroka@dkf.unibe.ch Received 23 February 2006; revised 23 May 2006; accepted 12 June 2006; published online II July 2006 inducible transcription factor, hypoxia-inducible factor 1 (HIF-1) (Shibaji et al, 2003). HIF-1 is a heterodimeric protein that is tightly regulated through the oxygen-dependent degradation of its $\alpha$ subunit. In the presence of oxygen, iron and 2-oxoglutarate HIF-1 $\alpha$ protein is hydroxylated by a class of enzymes termed HIF prolyl hydroxylases. The hydroxylation leads to its rapid proteosomal degradation in a von Hippel Lindau protein-dependent manner (Wang and Semenza, 1993a; Salceda and Caro, 1997; Huang et al, 1998). Hypoxia can be mimicked by the heavy metal cobalt chloride $\left(\mathrm{CoCl}_{2}\right)$, the iron-chelating agent, deferoxamine (DFX) or an inhibitor of the prolyl hydroxylases dimethyloxaloylglycine (DMOG), which all lead to the stabilisation of HIF- $1 \alpha$ protein (Brahmachari and Joseph, 1973; Wang and Semenza, 1993b; Ivan et al, 2001). In tumours with a poor oxygen supply, HIF-1 target genes are induced, which help cell survival and encourage a more aggressive tumour phenotype by promoting growth, invasion and metastasis (Hockel et al, 1996; Vaupel et al, 2001; Yoon et al, 2001).

$\mathrm{N}$-myc downstream-regulated gene 1 (NDRG1) is a recently described protein that is induced by cellular stress, in particular, it is significantly upregulated by hypoxia through HIF-1-dependent and -independent mechanisms (Park et al, 2000; Salnikow et al, 2000; Salnikow et al, 2002; Karaczyn et al, 2005). Other stressinducing agents, such as homocysteine and tunicamycin (Kokame et al, 1996), nickel compounds (Zhou et al, 1998), synthetic retinoids (Piquemal et al, 1999) and compounds that lead to cellular differentiation (van Belzen et al, 1997) can also modulate its expression. 
The precise biological function of NDRG1 is still not known, but various studies support its role as a potential tumour suppressor protein. Overexpression of NDRG1 in vitro results in morphological changes typical of cell differentiation and is inversely related to tumour growth and metastasis (Kurdistani et al, 1998; Guan et al, 2000; Bandyopadhyay et al, 2003; Bandyopadhyay et al, 2004a). Furthermore, its expression is increased by the tumour suppressor proteins p53 and PTEN (Kurdistani et al, 1998; Bandyopadhyay et al, 2004b) and clinical data have shown that its presence is statistically correlated with an increased survival of patients diagnosed with prostate cancer or liver metastasis from colorectal cancers (Bandyopadhyay et al, 2003; Shah et al, 2005).

NDRG1 mRNA is broadly expressed in many normal tissues, whereas its protein is generally restricted to cells of epithelial origin (Lachat et al, 2002). In some cancers, NDRG1 has been proposed to be a tumour marker because it is highly expressed in malignant compared to normal tissue of the same origin (GomezCasero et al, 2001; Nishie et al, 2001; Cangul et al, 2002b). However, the reliability of NDRG1 as a tumour marker is still undecided because its expression was initially shown to be repressed in colorectal cancer cells compared to the welldifferentiated normal colon epithelial cells (van Belzen et al, 1997). Furthermore, NDRG1 is a highly stable protein and has been suggested as a prognostic marker for hypoxic regions within a tumour mass (Park et al, 2000; Cangul et al, 2002b; Lachat et al, 2002).

Thus far, NDRG1 expression has yet to be studied in pancreatic cancer. We hypothesised that NDRG1 may be a novel indicator of malignant cells in the pancreas as hypoxia is a general feature of these tumours. The data presented in this study demonstrate that regardless of the hypoxic environment, there is a selective expression of NDRG1 in the pancreatic tumour cells. Therefore, we suggest that the determining factor of NDRG1 expression in pancreatic cancer is not hypoxia, but rather the differentiation status of the tumour.

\section{MATERIALS AND METHODS}

\section{Immunohistochemistry}

Human pancreatic samples were obtained at our institution from consented patients by standard surgical oncology procedures. Tissue samples from patients diagnosed with pancreatic cancer $(n=27)$ and pancreatic intraepithelial neoplasia (PanIN) $(n=6)$ were compared to samples taken from tumour-free resection margins $(n=11)$ and normal tissues obtained by organ donation or from patients with nonpancreatic diseases $(n=7)$. Formalinfixed samples were paraffin embedded and cut into $5 \mu \mathrm{m}$ thin sections for analysis. Deparaffinised sections were microwave heated for $20 \mathrm{~min}$ in $0.01 \mathrm{M} \mathrm{Na}$-citrate, $\mathrm{pH} 6.4$, for antigen retrieval. Endogenous peroxidases were blocked by $0.3 \% \mathrm{H}_{2} \mathrm{O}_{2}$ in methanol for $30 \mathrm{~min}$. Sections were incubated with either affinity-purified polyclonal rabbit anti-NDRG1 antibody $\left(1: 100\right.$, Zymed ${ }^{\mathbb{R}}$ Laboratories Inc., 52-3557, San Francisco, CA, USA), a polyclonal affinitypurified antibody raised in sheep against the full-length protein (1:3000, Kinasource AB-160 Limited, Scotland, UK) or with a monoclonal antibody against HIF- $1 \alpha$ (clone H1alpha67-sup; Novus Biologicals Inc., Colorado, USA) overnight at $4^{\circ} \mathrm{C}$. Specificity of the NDRG1 antibody from Zymed ${ }^{\circledR}$ was confirmed by blocking with the peptide immunogen. Sections were further developed with components of the Vectastain ${ }^{\mathbb{R}}$ Kit (Vector Laboratories Inc., Burlingame, CA, USA) according to the manufacturer's instructions. Immunoreactivity was developed using $3,3^{\prime}$-diaminobenzidine as the peroxidase substrate and nuclei were counterstained with haematoxylin. Negative controls were performed by substituting the first antibody with rabbit IgG (Dako, Schweiz AG, Baar, $\mathrm{CH})$. For histological analysis, serial sections were stained with haematoxylin and eosin and documented using a Leica DMRB microscope with IM50 Leica imaging software. The samples were evaluated by a pathologist (RW) and classified according to Klöppel's grading (Klöppel et al, 2000). In brief, G1 $(n=3)$ was stated in samples bearing well-differentiated duct-like glands, intensive mucin production, $<5$ mitoses per 10 high-power fields (HPF), little nuclear polymorphism or polar arrangement. G2 $(n=15)$ was stated in samples bearing moderately differentiated duct-like and tubular glands, irregular mucin production, 6-10 mitosis per $10 \mathrm{HPF}$ and moderate nuclear polymorphism. G3 $(n=9)$ was stated in samples bearing poorly differentiated glands, mucoepidermoid and pleomorphic structures, abortive mucin production, $>10$ mitosis per $10 \mathrm{HPF}$ and marked nuclear polymorphism and increased nuclear size. The intensity of immunohistochemical staining was scored 0 for no staining or from 1 to 3 , if cells were positively stained in more than $10 \%$ of the tumour. A score of 1 corresponded to weak and partial cell staining, 2 represented weak and complete staining and 3 for strong and complete staining. The mean intensity of $5 \mathrm{HPF}$ per section was calculated.

\section{Cell lines and culture conditions}

Human pancreatic cancer cells Capan-1 (moderately differentiated) and Panc-1 (poorly differentiated) were purchased from ATCC (LCG Promochem, Molsheim, France) and cultured in Dulbecco's modified Eagle's medium supplemented with $20 \%$ heatinactivated fetal bovine serum for Capan-1 and $10 \%$ for Panc-1, $100 \mathrm{U} / \mathrm{ml}$ penicillin and $100 \mu \mathrm{g} / \mathrm{ml}$ streptomycin (all from Life Technology, Paisley, Scotland) and incubated at $37^{\circ} \mathrm{C}$ in a humidified atmosphere with $5 \% \mathrm{CO}_{2}$. Hypoxic culture conditions were performed in a microaerophilic system (Ruskinn, Biotrace International, Bridgend, $\mathrm{UK}$ ) at $2 \% \mathrm{O}_{2}, 5 \% \mathrm{CO}_{2}$ and $93 \% \mathrm{~N}_{2}$ for 2, $4,12,24$ and $48 \mathrm{~h}$. To test additional activators of HIF- $1 \alpha$, cells were exposed to $125 \mu \mathrm{M}$ DMOG (Alexis Biochemicals, Lousen), $100 \mu \mathrm{M} \mathrm{CoCl}{ }_{2}$ (Sigma, Bucks, CH) or $100 \mu \mathrm{M}$ DFX (Sigma, Bucks, $\mathrm{CH})$.

\section{RNA extraction and real-time PCR}

Total RNA was extracted with TRIzol ${ }^{\circledR}$ (Life Technologies, Paisley, Scotland) according to the manufacturer's instructions. One microgram of total RNA was DNase treated (Promega, Madison, WI, USA) and reverse transcribed into cDNA with a commercial kit (Qiagen, Hilden, Germany). FAM ${ }^{\mathrm{TM}}$ dye-labelled TaqMan ${ }^{\mathbb{R}}$ MGB probes and polymerase chain reaction (PCR) primers were purchased for human NDRG1 and VEGF at Applied Biosystems (Warrington, UK). As internal positive control, 18S was used with a VIC ${ }^{\mathbb{R}}$ dye-labelled TaqMan ${ }^{\mathbb{R}}$ MGB probe. Real-time PCR was performed using ABI PRISM ${ }^{\mathrm{TM}} 7000$ Sequence Detector System (Applied Biosystems). The amplification conditions were as follows: 40 cycles at $95^{\circ} \mathrm{C}$ for $15 \mathrm{~s}$ (denaturation step) and $60^{\circ} \mathrm{C}$ for $1 \mathrm{~min}$ (combined annealing-extension step). Each experiment was carried out in triplicate. Mean cycle threshold $\left(C_{\mathrm{t}}\right)$ values were calculated for $18 \mathrm{~S}$ and the reporter gene. $C_{\mathrm{t}}$ values for NDRG1 and VEGF were normalised against the internal ribosomal RNA (18S) control probe to calculate $\Delta C_{\mathrm{t}}$ values. $\Delta \Delta C_{\mathrm{t}}$ values were calculated by subtracting the $\Delta C_{\mathrm{t}}$ values of cells under normoxia from the $\Delta C_{\mathrm{t}}$ value of cells under hypoxia. Fold increase was calculated using the formula $2^{-\left(\Delta \Delta C_{\mathrm{t}}\right)}$. Each experiment was repeated three times. After three repetitions mean and s.d. were calculated.

\section{Protein extraction and Western blotting}

For NDRG1 analysis, total cell lysates were prepared using $10 \mathrm{~mm}$ Tris ( $\mathrm{pH} 8.0$ ), $1 \mathrm{~mm}$ EDTA (pH 8.0), $150 \mathrm{~mm} \mathrm{NaCl}$ and $0.5 \% \mathrm{NP}-40$ with the inhibitors $1 \mathrm{mM} \mathrm{NaF}, 10 \mathrm{mM} \mathrm{Na}_{3} \mathrm{VO}_{4}, 1 \mathrm{mM}$ PMSF and $1 \times$ protease inhibitor cocktail (P-8340, Sigma). For HIF- $1 \alpha$, 
nuclear-enriched protein extracts were prepared as described previously (Jewell et al, 2001). Total protein concentrations were determined by Bio-Rad Protein Assay (Bio-Rad, Reinach, $\mathrm{CH}$ ) and equal amounts $(20 \mu \mathrm{g})$ were separated by sodium dodecyl sulphate-polyacrylamide gel electrophoresis (10\%). Proteins were transferred to nitrocellulose membrane using a semidry transfer system (Bio-Rad), blocked with $5 \%$ nonfat dry milk in $50 \mathrm{~mm}$ Tris $(\mathrm{pH} 7.5), 150 \mathrm{~mm} \mathrm{NaCl}, 0.1 \%$ Tween- 20 and incubated with the primary antibody (either sheep anti-NDRG1 $(0.1 \mu \mathrm{g} / \mathrm{ml}$, Kinasource AB-160, Scotland) or mouse anti-HIF-1 $\alpha$ (1:500, courtesy of Professor Max Gassmann, Zürich Switzerland)), rabbit anti- $\beta$-actin (1:500, Sigma A5060) or rabbit anti-Sp1 (Santa Cruz, SC-59, California, USA) overnight at $4{ }^{\circ} \mathrm{C}$. Membranes were incubated with either anti-sheep (1:3000, Dako), anti-mouse (1:10000, Pierce) or anti-rabbit (1:10 000, Dako) HRP-labelled secondary antibodies for $1 \mathrm{~h}$ at room temperature and developed with an enhanced chemiluminescent substrate (LiteAblot, Euroclone SpA, Lugano, Switzerland).

\section{Statistics}

Immunohistochemical data were analysed with the MannWhitney $U$-test. For the comparison of the real-time PCR data, $\Delta C_{\mathrm{t}}$ values were analysed by one-way analysis of variance (ANOVA) followed by Dunnett's multiple comparisons test. The statistical analysis software, SPSS (version 11.5), was used and $P<0.05$ was considered significant

\section{RESULTS}

NDRG1 protein is expressed in peritumoural, hyperplastic pancreatic areas

NDRG1 protein expression was not found in unmodified pancreatic tissue obtained from organ donors; specifically, there was no staining in the glandular epithelial cells of the acini or in the pancreatic islet cells (Figure 1A). However, pancreatic tissue obtained from tumour-free resection margins displayed strong staining for NDRG1 specifically in hyperplastic islets and hyperplastics ducts (Figure 1B). The peritumoral tissue is nonquiescent and considered reactive because it is under the influence of stimulating factors secreted by the tumour. The observed staining in these areas demonstrates that NDRG1 is expressed in nontumoral reactive pancreatic tissue.

\section{NDRG1 protein as a marker of pancreatic cancer differentiation}

Samples from patients diagnosed with pancreatic cancer were graded G1-3 (Klöppel et al, 2000) or as a PanIN. In all the samples, NDRG1 staining was restricted to the tumour epithelial cells and no staining was visible in fibrocytes of the desmoplastic reaction. In PanIN (Figure 1C) and in well-differentiated tumour regions (G1, n=3) (Figure 1D), there was a distinct staining of the epithelial cells. Moderately differentiated tumour regions (G2, $n=15$ ) showed a less prominent expression with patchy and irregular patterns on the membranes (Figure 1E). The median intensity score of G2 graded tumours was 1.8 with an interquartile range of 1.3-2.0. In comparison, there was nominal staining for NDRG1 in tumours that lost histopathological signs of differentiation (G3, $n=9$ ) (Figure $1 \mathrm{~F}$ ). The median intensity score of G3 graded tumours was 0.8 with an interquartile range of 0.6-1.4. This was significantly lower than in G2 graded tumours $(P=0.014)$. Furthermore, on resection margins it was frequently noted that, nonmalignant, highly differentiated tubular complexes in reactive pancreatic areas showed a stronger staining than the adjacent tumour cells (Figure 2).

Cellular hypoxia is a characteristic feature of pancreatic tumours and is generally known to act as potent inducer of NDRG1 expression. Using HIF- $1 \alpha$ expression as a marker for tumour hypoxia, we demonstrate that in both differentiated and undifferentiated pancreatic tumours HIF- $1 \alpha$ protein is stabilised. As expected, immunoreactivity for HIF- $1 \alpha$ was observed in the nuclei of tumour cells (Figure 3). In serial sections, NDRG1 was colocalised only in well-differentiated tumour regions.

\section{Hypoxia-induced upregulation of NDRG1 is influenced by pancreatic cancer cell differentiation}

To test whether hypoxia-induced expression of NDRG1 is dependent on differentiation, two pancreatic cancer cells lines, the moderately differentiated Capan-1 and the poorly differen-
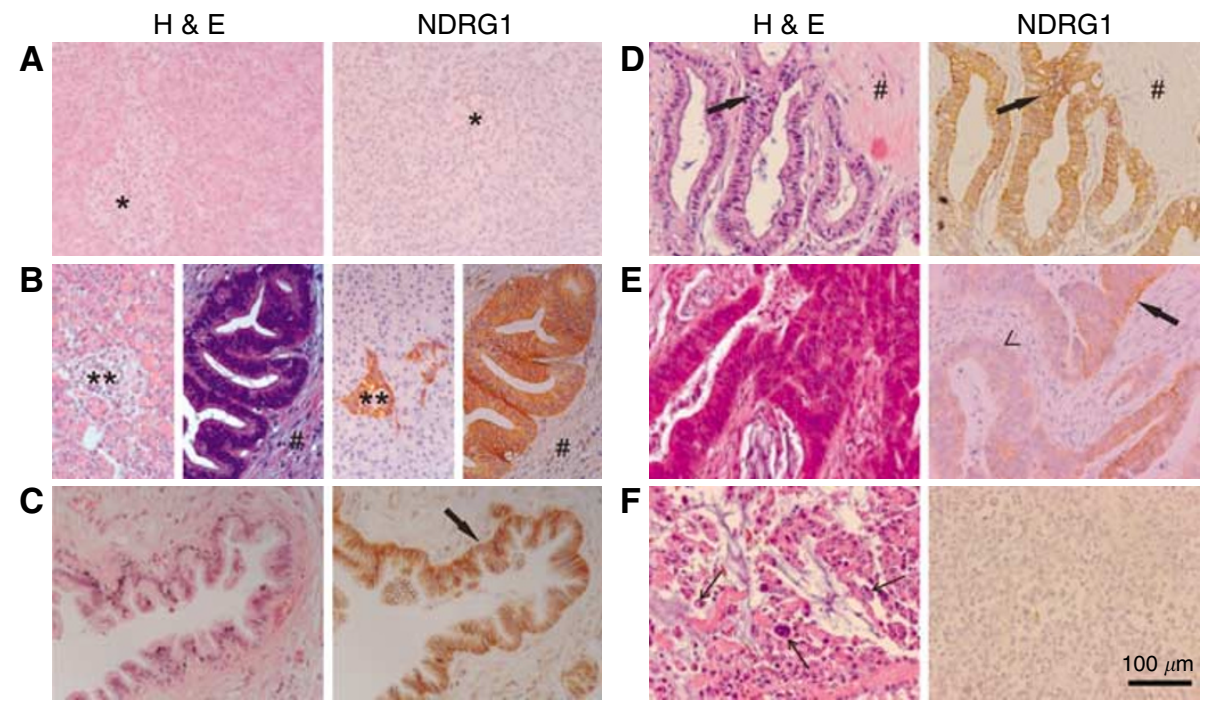

Figure I Photomicrographs of haematoxylin and eosion staining and NDRGI immunohistochemistry of pancreatic tissue sections (original magnification $\times 200$ ). (A) Normal pancreatic tissue from organ donors, with the pancreatic islets (*) surrounded by acini. (B) Peritumoral tissue with hyperplastic islets $(* *)$, hyperplastic ducts and fibrotic peritumoral tissue $(\#)$. (C) PanlN of the main duct $(\rightarrow)$. (D-F) Ductal adenocarcinomas of the pancreas, $(\mathbf{D})$ welldifferentiated tumour $(\rightarrow)$, embedded in the tumour stroma $(\#)$. (E) Moderately differentiated tumour with strongly staining malignant cells $(\rightarrow)$, beside malignant cells showing a faint staining $(<)$. (F) Undifferentiated tumour characterised by polynuclear cells $\leftarrow$. 
tiated Panc-1, were cultured either at $21 \% \mathrm{O}_{2}$ (normoxia, $\mathrm{N}$ ) or at $2 \% \mathrm{O}_{2}$ (hypoxia, $\mathrm{H}$ ). Exposure to $2 \% \mathrm{O}_{2}$ is sufficient to stabilise the $\alpha$-subunit of HIF-1 protein (Figure 4). HIF- $1 \alpha$ is stabilised and strongly detected by Western blot in nuclear protein extracts from cells cultured at $2 \% \mathrm{O}_{2}$ compared to normoxic controls in both tumour cell lines. Equal amounts of protein were controlled for with Sp1. VEGF mRNA expression was examined by real-time PCR as a control for the induction of an established HIF-1-dependent gene. Both cell lines show a significant 4-6-fold increase of VEGF mRNA after $12 \mathrm{~h}$ that was maintained up to $48 \mathrm{~h}$ of exposure to hypoxia (Figure 5).

Capan-1 and Panc-1 cells constitutively express similar levels of NDRG1 mRNA under normoxic conditions (data not shown). Under hypoxia, however, NDRG1 mRNA was upregulated 10-fold after $2 \mathrm{~h}$ and steadily increased reaching a 60 -fold induction after $24 \mathrm{~h}$ in the moderately differentiated Capan-1 cells. In contrast, there was no significant increase of NDRG1 mRNA at any time point tested in the poorly differentiated Panc-1 cells (Figure 6A). By Western blot, there was no expression of NDRG1 protein in both cell lines cultures under normoxic conditions. Yet, consistent with the mRNA analysis, NDRG1 protein was detected after $2 \mathrm{~h}$ of hypoxia and its level steadily increased reaching a maximum expression after $48 \mathrm{~h}$ in Capan-1 cells. There was no NDRG1 protein expression at all time points tested in Panc-1 cells. Equal amounts of protein were controlled for with $\beta$-actin (Figure 6B).

To confirm that NDRG1 expression is dependent on the cellular differentiation status of cells, other activators of HIF- $1 \alpha$ were tested. There was a strong induction of NDRG1 protein in Capan-1

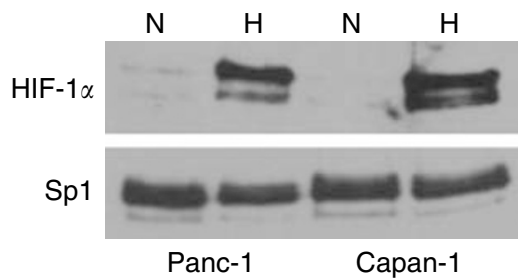

Figure $4 \mathrm{HIF}-\mid \alpha$ protein is stabilised in Capan-I and Panc- I cells under hypoxia. Nuclear enriched protein extracts from cells cultured either under normoxia $(\mathrm{N})$ or hypoxia $\left(\mathrm{H}: 2 \% \mathrm{O}_{2}\right)$ for $24 \mathrm{~h}$. Proteins were analysed by Western blot using a monoclonal antibody against HIF-I $\alpha(\mid 20 \mathrm{kDa})$ or a rabbit polyclonal antibody against SpI $(87 \mathrm{kDa})$ to control for equal nuclear protein loading. Signals were developed with enhanced chemiluminescence.

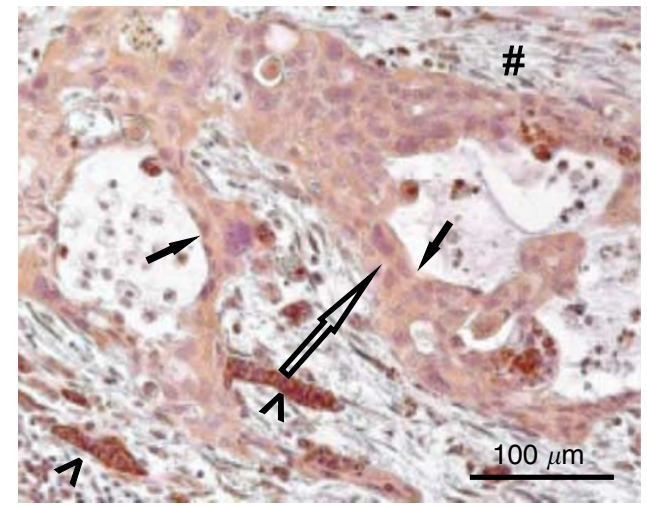

Figure 2 Photomicrograph of NDRGI immunohistochemistry (original magnification $\times 200$ ) of a moderately differentiated ductal adenocarcinoma of the pancreas $\rightarrow$, surrounded by fibrotic tissue (\#), with embedded regenerating tubular complexes $(<)$. \& The possible pathomechanism of dedifferentiation.

\section{Capan-1}

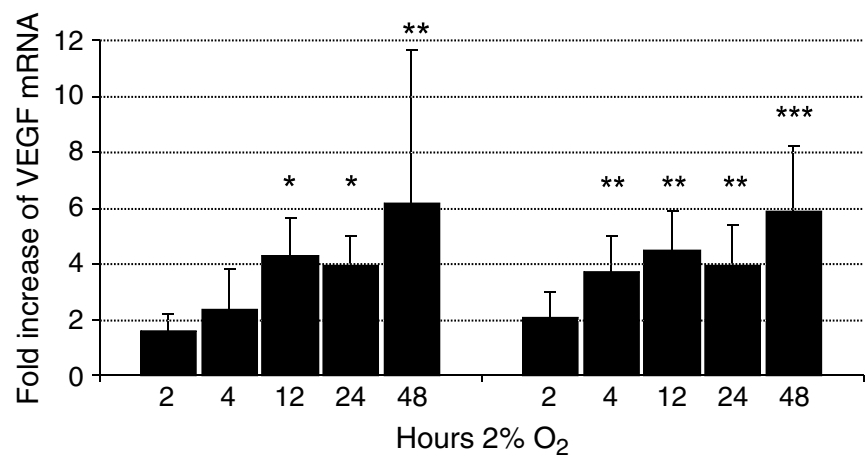

Figure 5 VEGF mRNA is equally upregulated in both Capan-I and PancI cells under hypoxia. Cells were grown under hypoxic conditions $\left(2 \% \mathrm{O}_{2}\right)$ for 2, 4, 12, 24 and $48 \mathrm{~h}$. The bars represent the mean fold increase plus s.d. of hypoxic cells compared to normoxic controls. Results are from three independent experiments. Statistics were calculated by ANOVA followed by Dunnett's multiple comparisons test, $* P<0.05$, $* * P<0.0$ I, ${ }^{*} * * P<0.001$.
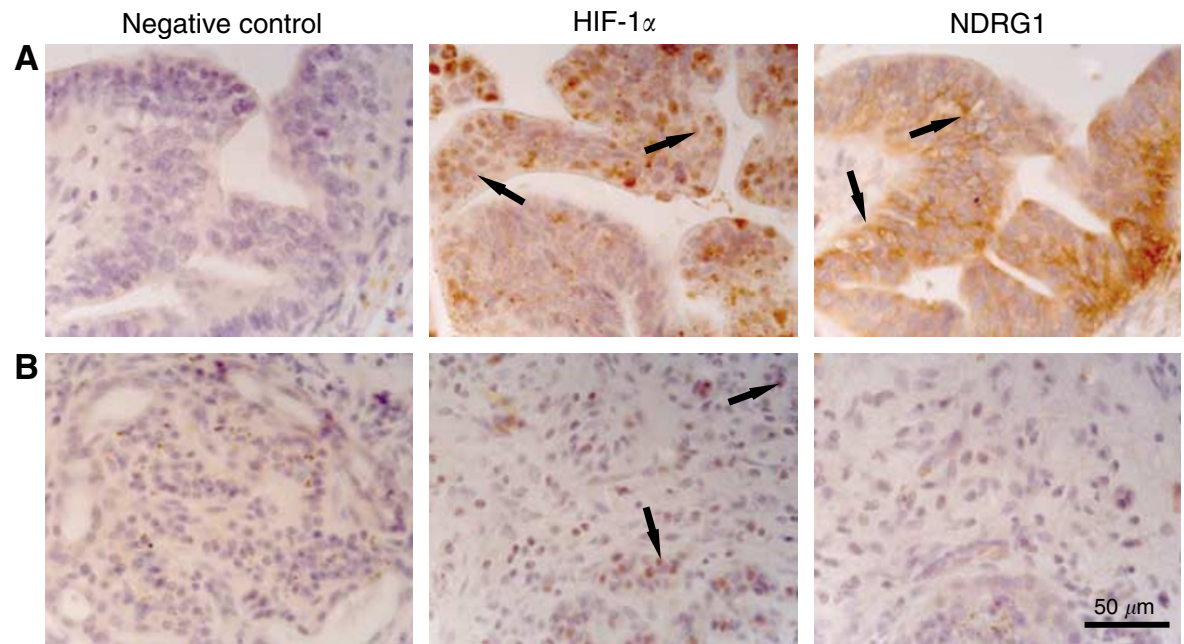

Figure 3 Photomicrographs of $(\mathbf{A})$ moderately differentiated and $(\mathbf{B})$ poorly differentiated ductal adenocarcinomas of the pancreas stained for HIF- $\mid \alpha$ and NDRGI (original magnification $\times 400$ ). $(\rightarrow)$ Indicating positive reactivity in tumour cells. 
A

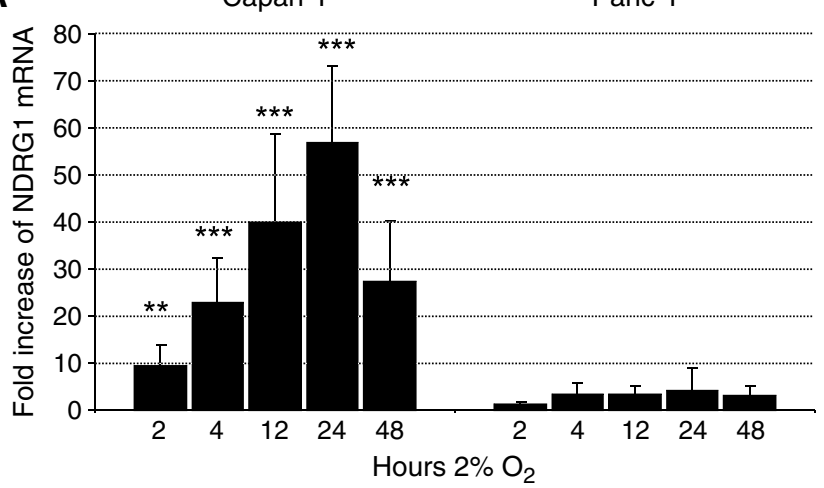

B

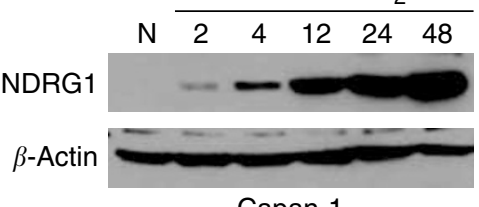

Capan-1

Figure 6 Comparison of NDRGI mRNA (A) and protein (B) expression in Capan-I and Panc-I cell lines. (A) Refer to Figure 5 for explanation. (B) Cells were exposed to normoxia $(\mathrm{N})$ or hypoxia $\left(2 \% \mathrm{O}_{2}\right)$ for 2, 4, 12, 24 or $48 \mathrm{~h}$. Total protein lysates were analysed by Western blot with a sheep anti-NDRGI antibody $(43 \mathrm{kDa})$. Signals were developed with enhanced chemiluminescence. $\beta$-actin $(42 \mathrm{kDa}$ ) is shown as a control for equal protein loading.

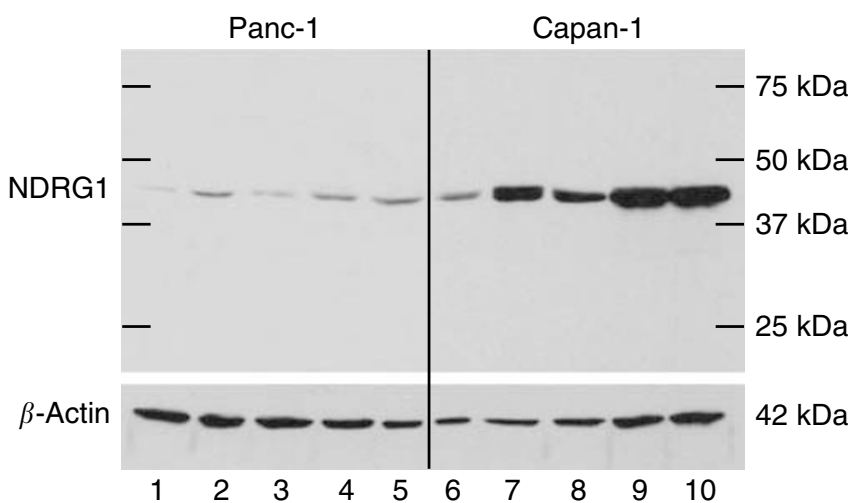

Figure 7 Comparison of NDRG I expression in Panc-I and Capan- I cell lines exposed to HIF-I $\alpha$ activators. Panc-I and Capan-I cell lines were exposed to several HIF-I $\alpha$ activators for $24 \mathrm{~h}$. Total protein lysates were analysed by Western blot with a sheep anti-NDRGI antibody $(43 \mathrm{kDa})$. $\beta$-Actin $(42 \mathrm{kDa})$ is shown as a control for equal protein loading. Lanes I and 6: normoxia; lanes 2 and 7: $125 \mu \mathrm{M}$ DMOG; lane 3 and 8: $100 \mu \mathrm{M}$ cobalt chloride; lanes 4 and 9: $100 \mu \mathrm{M}$ DFX; and lanes 5 and 10: hypoxia with $2 \% \mathrm{O}_{2}$.

cells incubated with DMOG, $\mathrm{CoCl}_{2}$, DFX and under hypoxia in comparison to Panc-1 cells, at equal loading and exposure time (Figure 7). Analysis of NDRG1 mRNA confirmed these results (data not shown). Of note, unlike in the previous Western blots shown, we found faint signals in the Panc-1 cells, which are a result of increased antibody sensitivity.

Taken together, this series of experiments suggest a selective loss of NDRG1 expression despite HIF-1 $\alpha$ stabilisation in the undifferentiated pancreatic cell line, Panc-1.

\section{DISCUSSION}

NDRG1 is strongly induced by hypoxia, one of the key characteristics of pancreatic cancer, thus our first goal was to establish NDRG1 as a tumour marker for this aggressive malignancy. Initially, our data in the pancreas were consistent with previous reports on other cancers (Gomez-Casero et al, 2001; Nishie et al, 2001; Cangul et al, 2002a), showing that NDRG1 protein is highly expressed in tumours compared to normal tissue of the same origin. However, pancreatic cancers induce a strong peritumoral desmoplastic reaction characterised by fibrosis and hypoxia. Within this region, where pancreatic regeneration is an active process, we observed a strong staining of newly formed, highly differentiated tubular complexes as well as in hyperplastic ducts and islets. The high NDRG1 expression levels found in these reactive areas supports studies that have demonstrated its modulation during differentiation and by multiple stress-inducing agents.

On closer examination, we observed that PanIN and areas consisting of well-differentiated cells were strongly stained within pancreatic tumours. Conversely there was very little to no expression of NDRG1 protein in poorly differentiated cells, although we showed HIF- $1 \alpha$-positive nuclei in these regions. This observation was in agreement with studies of colorectal and prostatic cancer, in which NDRG1 was reduced in poorly differentiated adenocarcinoma compared to well-differentiated cells (van Belzen et al, 1997; Guan et al, 2000; Caruso et al, 2004). The difference being that, quiescent apical colonic epithelia express NDRG1, whereas normal pancreatic cell types do not.

From a clinical point of view, the observed presence of NDRG1 in nontumoral tissue taken together with its negligible expression in undifferentiated tumours argues against its value as a reliable tumour marker. It may, however, be a potential marker to predict the differentiation status of pancreatic cancer cells. Within a tumour lesion, loss of expression would serve as a poor prognostic indicator and a tool to plan the adjuvant therapy. In a retrospective analysis, high levels of NDRG1 was associated with indolent tumour growth and with improved survival in patients diagnosed with colorectal cancer (Shah et al, 2005).

As pancreatic cancer is characterised as a hypoxic tumour, we next questioned why there was negligible NDRG1 expression in the undifferentiated tumour cells. Hypoxia can influence cellular phenotypes by altering the expression of specific genes and is generally thought to give pancreatic cancers cells an advantage by promoting factors beneficial for tumour growth and survival (Duffy et al, 2003). This idea is maintained by our in vitro experiments in which HIF- $1 \alpha$ protein and VEGF mRNA were upregulated by hypoxia in both cell lines tested. Whereas Panc-1, the more aggressive undifferentiated cell line, showed a modest increase of NDRG1 mRNA or protein under different HIF- $1 \alpha$ stabilizer, compared to the prominent response of the moderately differentiated tumour cell line, Capan-1. This suggests that the expression of NDRG1 may be dependent on cell differentiation. If indeed NDRG1 is a potential tumour suppressor protein, it would be a survival advantage for an aggressive cancer to shut down the ability to upregulate a growth inhibitory protein. The loss of ability to express NDRG1 would assist cells to dedifferentiate to a more aggressive phenotype with more metastatic potential. Recently, it has been suggested that hypoxia can induce dedifferentiation and genetic instability of tumour cells, which may account for the heterogeneity and aggressiveness of solid tumours (Reynolds et al, 1996; Jogi et al, 2002; Helczynska et al, 2003; Unruh et al, 2003).

NDRG1 is a very stable protein and has been proposed as an indicator of tumour hypoxia (Cangul et al, 2002a). From our studies, along with the published work of others, we would predict that its use as a marker of hypoxia would also be unreliable. The first point, as we suggest here, its expression is dependent on the differentiation status of cells within a hypoxic environment. 
Furthermore, other potential markers such as HIF- $1 \alpha$ and its target genes Glut-1 and CAIX were proven unreliable because of the influence of other regulating factors (Mayer et al, 2004, 2005a, b). In addition to oxygen deprivation, hypoxia-regulated genes can be influenced by nutrient deficiencies, oncogenic mutations and oxidative stress. NDRG1 expression is also modulated by ascorbate levels within a tumour microenvironment, directly demonstrating an alternative mechanism of its regulation (Karaczyn et al, 2005).

In this study, our data suggest that it is the differentiated cells that can express NDRG1 in a hypoxia-stressed environment. Hypoxic areas within solid tumours are diverse and nonuniform through the new formation and collapse of subfunctional blood vessels. This may account for the observed patchy pattern of NDRG1 expression we observed in moderately differentiated tumours. The mechanism by which this response is lost in undifferentiated cells warrants further investigations.

Pancreatic cancer is characterised by its predisposition to aggressively invade surrounding tissues, to metastasise early and extensively and to resist conventional chemoradiation treatment strategies. Although the precise function of NDRG1 is unknown, there is solid evidence that suggests it may suppress the invasive ability and spontaneous metastasis of cancer cells by inducing differentiation and reversing a metastatic phenotype. Further studies are aimed to clarify the function of this novel protein, and its role in the progression and metastasis of various cancers. Clinically important, the data provided suggest that NDRG1 may offer a powerful diagnostic tool for the grading of pancreatic cancers, whereas better characterising of the protein may help to decide on how aggressive the adjuvant therapy should be planned.

\section{ACKNOWLEDGEMENTS}

We thank Sonja Bisch-Knaden for the statistical analysis, Adrian Keogh, Cynthia Furrer and Peter Studer for technical assistance and Mattia Rizzi for scientific discussions. And we thank Professor A Zimmermann from the pathology at the University of Berne for providing us with PanIN slides. This work was supported by the Werner und Hedy Berger-Janser Stiftung for Cancer Research, No. $1 / 2004$ (to DS and DC).

\section{REFERENCES}

(Available from: http://seer.cancer.gov/csr/1975_2000/) (1975_2000) Surveillance Epidemiology and End Result. National Cancer Institute, $1975-2000$

Bandyopadhyay S, Pai SK, Gross SC, Hirota S, Hosobe S, Miura K, Saito K, Commes T, Hayashi S, Watabe M, Watabe K (2003) The Drg-1 gene suppresses tumor metastasis in prostate cancer. Cancer Res 63: $1731-1736$

Bandyopadhyay S, Pai SK, Hirota S, Hosobe S, Takano Y, Saito K, Piquemal D, Commes T, Watabe M, Gross SC, Wang Y, Ran S, Watabe K (2004a) Role of the putative tumor metastasis suppressor gene Drg-1 in breast cancer progression. Oncogene 23: $5675-5681$

Bandyopadhyay S, Pai SK, Hirota S, Hosobe S, Tsukada T, Miura K, Takano Y, Saito K, Commes T, Piquemal D, Watabe M, Gross S, Wang Y, Huggenvik J, Watabe K (2004b) PTEN up-regulates the tumor metastasis suppressor gene Drg-1 in prostate and breast cancer. Cancer Res 64: $7655-7660$

Brahmachari HD, Joseph S (1973) Cobalt compounds for the control of hypoxic stress. Aerospace Med 44: 636-638

Buchler P, Reber HA, Buchler M, Shrinkante S, Buchler MW, Friess H, Semenza GL, Hines OJ (2003) Hypoxia-inducible factor 1 regulates vascular endothelial growth factor expression in human pancreatic cancer. Pancreas 26: 56-64

Buchler P, Reber HA, Lavey RS, Tomlinson J, Buchler MW, Friess H, Hines OJ (2004) Tumor hypoxia correlates with metastatic tumor growth of pancreatic cancer in an orthotopic murine model. J Surg Res 120: 295-303

Cangul H, Salnikow K, Yee H, Zagzag D, Commes T, Costa M (2002a) Enhanced expression of a novel protein in human cancer cells: a potential aid to cancer diagnosis. Cell Biol Toxicol 18: 87-96

Cangul H, Salnikow K, Yee H, Zagzag D, Commes T, Costa M (2002b) Enhanced overexpression of an HIF-1/hypoxia-related protein in cancer cells. Environ Health Perspect 110(Suppl 5): 783-788

Caruso RP, Levinson B, Melamed J, Wieczorek R, Taneja S, Polsky D, Chang C, Zeleniuch-Jacquotte A, Salnikow K, Yee H, Costa M, Osman I (2004) Altered N-myc downstream-regulated gene 1 protein expression in African-American compared with caucasian prostate cancer patients. Clin Cancer Res 10: $222-227$

Duffy JP, Eibl G, Reber HA, Hines OJ (2003) Influence of hypoxia and neoangiogenesis on the growth of pancreatic cancer. Mol Cancer 2: 12

Gomez-Casero E, Navarro M, Rodriguez-Puebla ML, Larcher F, Paramio JM, Conti CJ, Jorcano JL (2001) Regulation of the differentiation-related gene Drg-1 during mouse skin carcinogenesis. Mol Carcinogen 32: $100-109$

Guan RJ, Ford HL, Fu Y, Li Y, Shaw LM, Pardee AB (2000) Drg-1 as a differentiation-related, putative metastatic suppressor gene in human colon cancer. Cancer Res 60: 749-755
Helczynska K, Kronblad A, Jogi A, Nilsson E, Beckman S, Landberg G, Pahlman S (2003) Hypoxia promotes a dedifferentiated phenotype in ductal breast carcinoma in situ. Cancer Res 63: 1441-1444

Hockel M, Schlenger K, Aral B, Mitze M, Schaffer U, Vaupel P (1996) Association between tumor hypoxia and malignant progression in advanced cancer of the uterine cervix. Cancer Res 56: 4509-4515

Hotz HG, Hines OJ, Masood R, Hotz B, Foitzik T, Buhr HJ, Gill PS, Reber HA (2005) VEGF antisense therapy inhibits tumor growth and improves survival in experimental pancreatic cancer. Surgery 137: $192-199$

Huang LE, Gu J, Schau M, Bunn HF (1998) Regulation of hypoxia-inducible factor lalpha is mediated by an $\mathrm{O}_{2}$-dependent degradation domain via the ubiquitin-proteasome pathway. Proc Natl Acad Sci USA 95: $7987-7992$

Ivan M, Kondo K, Yang H, Kim W, Valiando J, Ohh M, Salic A, Asara JM, Lane WS, Kaelin Jr WG (2001) HIFalpha targeted for VHL-mediated destruction by proline hydroxylation: implications for $\mathrm{O}_{2}$ sensing. Science 292: $464-468$

Jewell UR, Kvietikova I, Scheid A, Bauer C, Wenger RH, Gassmann M (2001) Induction of HIF-1alpha in response to hypoxia is instantaneous. FASEB J 15: $1312-1314$

Jogi A, Ora I, Nilsson H, Lindeheim A, Makino Y, Poellinger L, Axelson H, Pahlman S (2002) Hypoxia alters gene expression in human neuroblastoma cells toward an immature and neural crest-like phenotype. Proc Natl Acad Sci USA 99: $7021-7026$

Karaczyn A, Ivanov S, Reynolds M, Zhitkovich A, Kasprzak KS, Salnikow K (2005) Ascorbate depletion mediates up-regulation of hypoxia-associated proteins by cell density and nickel. J Cell Biochem 97(5): $1025-1035$

Klöppel G, Hruban RH, Longnecker DS, Adler G, Kern SE, Partanen TJ (2000) Pathology and Genetics of Tumours of the Digestive System. WHO Classification of Tumours. Ductal Adenorcarcinoma of the Pancreas. Lyon: IARC Press

Kokame K, Kato H, Miyata T (1996) Homocysteine-respondent genes in vascular endothelial cells identified by differential display analysis. GRP78/BiP And Novel Genes. J Biol Chem 271: 29659-29665

Koong AC, Mehta VK, Le QT, Fisher GA, Terris DJ, Brown JM, Bastidas AJ, Vierra M (2000) Pancreatic tumors show high levels of hypoxia. Int $J$ Radiat Oncol Biol Phys 48: 919-922

Kurdistani SK, Arizti P, Reimer CL, Sugrue MM, Aaronson SA, Lee SW (1998) Inhibition of tumor cell growth by RTP/rit42 and its responsiveness to p53 and DNA damage. Cancer Res 58: 4439-4444

Lachat P, Shaw P, Gebhard S, van Belzen N, Chaubert P, Bosman FT (2002) Expression of NDRG1, a differentiation-related gene, in human tissues. Histochem Cell Biol 118: 399-408

Mayer A, Hockel M, Vaupel P (2005a) Carbonic anhydrase IX expression and tumor oxygenation status do not correlate at the microregional level 
in locally advanced cancers of the uterine cervix. Clin Cancer Res 11: $7220-7225$

Mayer A, Hockel M, Wree A, Vaupel P (2005b) Microregional expression of glucose transporter-1 and oxygenation status: lack of correlation in locally advanced cervical cancers. Clin Cancer Res 11: 2768-2773

Mayer A, Wree A, Hockel M, Leo C, Pilch H, Vaupel P (2004) Lack of correlation between expression of HIF-1alpha protein and oxygenation status in identical tissue areas of squamous cell carcinomas of the uterine cervix. Cancer Res 64: 5876-5881

Niizeki H, Kobayashi M, Horiuchi I, Akakura N, Chen J, Wang J, Hamada JI, Seth P, Katoh H, Watanabe H, Raz A, Hosokawa M (2002) Hypoxia enhances the expression of autocrine motility factor and the motility of human pancreatic cancer cells. Br J Cancer 86: 1914- 1919 (doi: 10.1038/ sj.bjc.6600331)

Nishie A, Masuda K, Otsubo M, Migita T, Tsuneyoshi M, Kohno K, Shuin T, Naito S, Ono M, Kuwano M (2001) High expression of the Cap43 gene in infiltrating macrophages of human renal cell carcinomas. Clin Cancer Res 7: $2145-2151$

Park H, Adams MA, Lachat P, Bosman F, Pang SC, Graham CH (2000) Hypoxia induces the expression of a $43-\mathrm{kDa}$ protein (PROXY-1) in normal and malignant cells. Biochem Biophys Res Commun 276: 321 - 328

Piquemal D, Joulia D, Balaguer P, Basset A, Marti J, Commes T (1999) Differential expression of the RTP/Drg1/Ndr1 gene product in proliferating and growth arrested cells. Biochim Biophys Acta 1450: $364-373$

Reynolds TY, Rockwell S, Glazer PM (1996) Genetic instability induced by the tumor microenvironment. Cancer Res 56: 5754-5757

Salceda S, Caro J (1997) Hypoxia-inducible factor 1alpha (HIF-1alpha) protein is rapidly degraded by the ubiquitin-proteasome system under normoxic conditions. Its stabilization by hypoxia depends on redoxinduced changes. J Biol Chem 272: 22642-22647

Salnikow K, Blagosklonny MV, Ryan H, Johnson R, Costa M (2000) Carcinogenic nickel induces genes involved with hypoxic stress. Cancer Res 60: $38-41$

Salnikow K, Kluz T, Costa M, Piquemal D, Demidenko ZN, Xie K, Blagosklonny MV (2002) The regulation of hypoxic genes by calcium involves c-Jun/AP-1, which cooperates with hypoxia-inducible factor 1 in response to hypoxia. Mol Cell Biol 22: 1734-1741
Shah MA, Kemeny N, Hummer A, Drobnjak M, Motwani M, Cordon-Cardo C, Gonen M, Schwartz GK (2005) Drg1 expression in 131 colorectal liver metastases: correlation with clinical variables and patient outcomes. Clin Cancer Res 11: 3296-3302

Shi Q, Abbruzzese JL, Huang S, Fidler IJ, Xiong Q, Xie K (1999) Constitutive and inducible interleukin 8 expression by hypoxia and acidosis renders human pancreatic cancer cells more tumorigenic and metastatic. Clin Cancer Res 5: 3711-3721

Shibaji T, Nagao M, Ikeda N, Kanehiro H, Hisanaga M, Ko S, Fukumoto A, Nakajima Y (2003) Prognostic significance of HIF-1 alpha overexpression in human pancreatic cancer. Anticancer Res 23: 4721-4727

Sohn TA, Yeo CJ (2000) The molecular genetics of pancreatic ductal carcinoma: a review. Surg Oncol 9: 95-101

Unruh A, Ressel A, Mohamed HG, Johnson RS, Nadrowitz R, Richter E, Katschinski DM, Wenger RH (2003) The hypoxia-inducible factor-1 alpha is a negative factor for tumor therapy. Oncogene 22: $3213-3220$

van Belzen N, Dinjens WN, Diesveld MP, Groen NA, van der Made AC, Nozawa Y, Vlietstra R, Trapman J, Bosman FT (1997) A novel gene which is up-regulated during colon epithelial cell differentiation and downregulated in colorectal neoplasms. Lab Invest 77: 85-92

Vaupel P, Thews O, Hoeckel M (2001) Treatment resistance of solid tumors: role of hypoxia and anemia. Med Oncol 18: 243-259

Wang GL, Semenza GL (1993a) Characterization of hypoxia-inducible factor 1 and regulation of DNA binding activity by hypoxia. J Biol Chem 268: $21513-21518$

Wang GL, Semenza GL (1993b) Desferrioxamine induces erythropoietin gene expression and hypoxia-inducible factor 1 DNA-binding activity: implications for models of hypoxia signal transduction. Blood 82: $3610-3615$

Warren KW, Christophi C, Armendariz R, Basu S (1983) Current trends in the diagnosis and treatment of carcinoma of the pancreas. Am J Surg 145: $813-818$

Yoon DY, Buchler P, Saarikoski ST, Hines OJ, Reber HA, Hankinson O (2001) Identification of genes differentially induced by hypoxia in pancreatic cancer cells. Biochem Biophys Res Commun 288: $882-886$

Zhou D, Salnikow K, Costa M (1998) Cap43, a novel gene specifically induced by $\mathrm{Ni}^{2+}$ compounds. Cancer Res 58: $2182-2189$ 